\title{
Implementation of Task-based Language Teaching in Classes of Second Language Acquisition
}

\author{
Ma Zhao \\ 31th Floor Tianjin Center No.219, Nanjing Street, Heping District, Tianjin, China \\ mazhao35@sina.com
} Keywords: Task-based language teaching, 3P approach, Second language acquisition, English
teaching, Advantages of TBLT, Limitations of TBLT

\begin{abstract}
Since its invention, Task-based language teaching (TBLT) has always aroused interests among experts in studying, exploring and applying such approach in daily teaching. With the increasing significance of English, efficiency of English teaching in China is considered as a vital issue. In second language acquisition, task-based language teaching has been proved from many aspects to yield satisfactory results, at least to some extent. The paper aims at analyzing advantages of TBLT as a preferable method adopted in SLA classes by comparing differences between TBLT and conventional 3P (Present, Practice and Produce) approach and coming up with limitations of TBLT for future studies.
\end{abstract}

\section{Introduction}

The first appearance of task-based language teaching (TBLT) was witnessed in 1979, when an Indian scholar N. S. Prabhu, one of the pioneers in language teaching, conducted his Bangalore Project in Indian high-tech area. The project initially proposed a variety of tasks, in which students were asked to learn language in the course of working on those communicative tasks [1]. This project is universally regarded as the first try-out of designing tasks for language teaching, which drew public attentions in this field. Over the past several decades, scholars made a wide range of attempts to implement TBLT in language teaching classes, classes of second language acquisition (SLA) in particular. Susan Gass proposes that language should be acquired through a series of steps: comprehended input, intake, internalization and output [2]. Her proposition corresponds to three stages carried out in TBLT: pre-task, task cycle and after-task - language focus [3]. In the first stage, the duty of teachers is to list topic, requirements of the task, then introduce corpus related to such task and by all means facilitate students comprehend those language materials. In other words, students in this stage should attain to comprehended input. The second stage is designed to create a communicative context, in which students could exchange ideas on this task and absorb relevant corpus. That is to say, they achieve goals of language intake and internalization in this process. Then they manage to produce language output. Finally, students' reports will be assessed and the question that to what extent students could incorporate language materials within themselves will be answered. As a result, TBLT seems to be appropriate for SLA. Then the paper is expected to further discuss the following questions:

(1). Compared with 3P method, why TBLT is more preferable for SLA classes

(2). How could TBLT be employed in SLA classes

(3). From what aspects TBLT could be improved.

\section{Differences between 3P method and TBLT}

3P and TBLT are both subordinated to Communicative Language Teaching (CLT). Later on, Howatt made a breakthrough by making clear classification of the two approaches, 3P was defined as weak versions of CLT while TBLT was called strong versions [4]. They differ from each other in the following ways: 
The primary concern should be given for teaching principles. 3P method lays its emphasis on forms so that the importance of contents and meanings is diminished [5]. Given this, students have to listen carefully to teachers' illustrations and then to put knowledge into practice with clear intentions, in an attempt to master the language and relevant grammatical structures. Such principle that drives students learn language with consciousness corresponds to the description of Krashen's Learning Hypothesis [6]. On the contrary, TBLT declares its identity as meaning-focused approach and then students are led to complete the task under communicative circumstances [7.8]. In this course, students are expect to leave forms aside but concentrate on meanings of their utterances, which coincides with Acquisition Theory proposed by Krashen [9]. He stresses that acquiring language in an natural and random sequence could benefit students' comprehension and manipulation of language, but learning can do no better than that.

Second, difference between 3P approach and TBLT is embodied in role of teachers. A teacher works as a controller when s/he is employing 3P in the class, in which s/he delivers a presentation of the knowledge at length and puts strict control of students' language [10]. So that it is inevitable that the center role of teacher results in an eclipse of the role of students, whose interests can not be taken into account. However, when TBLT is implementing in a class, the teacher is more likely to be a facilitator. With no attempt to control students' language, the teacher leaves many options for students to figure out their language, such as consulting a dictionary or grammar book and interacting with their classmates. Van den Branden states that a teacher supporting task performance in such a way as to trigger process is considered to be crucial to SLA [11].

Finally, 3P approach and TBLT impose different effects in terms of students' motivation. Running counter to the pattern of SLA that effective language acquisition ought to be achieved under authentic contexts, students can hardly be motivated to participate in 3P classes, because communicative situations designed by 3P approaches have nothing to do with the real world. It is no wonder that Leaver \& Willis doubt that whether or not students can make full use of language learnt from classes outside the classroom [12]. Whereas, TBLT is able to lessen the pressure from individual work by assigning group works to students. Lamy calls for a reduction of learners' anxiety thus making task performance more efficient [13]. Moreover, Willis also notices that real-life topics planned in TBLT raise students' awareness of significance of getting involved in the communicative task, since language acquired from the task could probably be applied in certain situations in daily life. Thus the process of SLA will be accelerated with such realization, which prompts students to intake a wide range of input and produce target language output [14-15].

\section{Practice of TBLT in SLA Classes}

The previous part has illustrated advantages of TBLT adopted in SLA classes from three angles. Among those ample theories of TBLT, characteristics of a task are denoted by the concept of TBLT in Skehan's version, "a task is an activity in which meaning is primary; a task should have a lot in common with daily life; learners are not given other people's meanings to regurgitate; task completion has some sort of priority; the assessment of the task is in terms of outcome.” [16]. The task not only constructs the closest matching environment of SLA: when the boundary between the class and outside world becomes vague, students are easier to acquire the language with a subconscious state of mind [17], it but also reinforces their language input and output. Thus when a task related to real world is carrying out in the class, students are actively engaged in interactions with others and in negotiations of meaning. In accordance with Long's theory, interaction and language input are regarded as the two major roles played in SLA [18]. Plus, through negotiation of meaning, students can compare their first language with the target language and form a conscious awareness of the gap [19]. Then they are able to comprehend and modify input. More specifically, a concrete and highly viable mode of TBLT was provided by Willis in 1996, which divides the entire task into three stages: pre-task, task cycle and language focus.

Before the task, teachers have to make informed decisions about task design, selection and sequencing over extended periods of instruction [20]. 
In the first stage, a teacher should inform students with the task and help them form their own interpretations and put the task into action [21]. Then teacher can introduce language input that might be conducive to students' preparation for the task.

After that, the task is moved on to the second stage, in which the role of the teacher is switched to a facilitator, who leaves groups to interpret the task and process language by group discussions. On one hand, while moving around groups, the teacher helps students develop their viewpoints, clarify their language and promote their discussions. On the other hand, working in groups is expected to bring forth fruitful result in terms of language output, as Dundis and Benson conclude that students would bring their potential into full play if they had a sense of unified group with a shared responsibility [22].

Discussions is followed by students' reports. After a variety of communicative methods devised by the teacher ahead of time, the time has come for students to deliver their language output. It is supported by Output Hypothesis first propounded by Swain, who suggests that "practice makes perfect". Aiming to enhance fluency and accuracy of language, sufficient opportunities to practice language output should be supplied to students besides abundant language input [23].

In the final part, The teacher values students' language output and then enhance the importance of outcome [24]. Based on the foundational theory of TBLT, teacher's assessment should put students' opinions in the primary position and focus on form works as an auxiliary element.

\section{Limitations of TBLT Employed in SLA Classes}

In the field of SLA, an omnipotent teaching method still remains a myth. The implementation of TBLT in SLA classes in China is away from being a thorough success although the invention of TBLT is in respond to constrains of 3P approach.

First, it should be noticed that tasks designed by teachers keep distance from real-life situations. Students' motivation and interests become absent in consequence of the lost of possible application of language learnt from classes in real life. As a result, the concept of TBLT should be kept in mind, as Bachman and Palmer mention, that a task involves students in using language for the purpose of answering the call from real life situations [25]. Then teachers will make discreet decisions about task selections.

Also, interventions from teachers should be lessened so that the role of being a facilitator could be maintained. Dornyei defines the role of teachers in TBLT in this way, "maintaining motivation and helping them to overcome obstacles in the task process is a central role a teacher as facilitator has" [26]. Strict controlling on language discourages students' confidence and redirects their attention to form instead of meaning. Krashen states that it is reasonable to put form in subordinate position to meaning for the purpose of acquiring the language.

Finally, assessment in language focus is still viewed as a controversial topic in the field. Although proliferation has been realized in assessments of reading and writing, it is still much to be done in speaking and listening. Therefore new and effective assessments for the two parts are waiting to be explored in the future.

\section{Conclusion}

Task-based has been proved to conform to principles of SLA in many ways. The conclusion can be drawn from the comparison with 3P approach that TBLT can construct real life contexts similar to countries with target language, then students efficiency of acquiring language is prone to be promoted, since Wilkins points out a fact that learners living in countries with target language perform better than their counterparts staying in hometowns [27]. Besides, negotiation of meaning provided by TBLT and conversion of central role from teachers to students impel students to participate in the process of language acquisition. Motivation is considered as an indication of the amount of time that people will spend in language acquisition. The higher a student's motivation is, the longer s/he is willing to devote to language acquisition, the richer outcome s/he will achieve 
[28]. Even though TBLT has inherent limitations, its promising future in SLA can be looked forward to.

\section{References}

[1] N.S. Prabhu. Second Language Pedagogy. Oxford: Oxford University Press,1987.

[2] Susan Gass. Second Language Acquisition: An Introductory Course. New Jersey: Lawrence Erlbaum Associates,2001.

[3] Dave Willis and Jane Willis. Doing Task-based Teaching. Oxford University Press, 2007, pp. 56-63

[4] A. Howatt. A History of English Language Teaching. Oxford: Oxford University Press,1994.

[5] Michael Long. Focus on Form: A design Feature in Language Teaching Method. In Foreign Language Research in Cross-cultural Perspective. Amsterdam: John Benjamins,1991, pp.39-52.

[6] S.D. Krashen. The Input HypothesisL Issues and Implications. New York: Longman,1985.

[7] W. Littlewood. Communicative Language Teaching: An Introductory Course. Cambridge: Cambridge University Press,1981.

[8] D. Nunan. Designing Tasks for The Communicative Classroom. Cambridge: Cambridge University Press,1998.

[9] S.D. Krashen. Principles and Practice in Second Language Acquisition. New York: Pergamon Press Ltd,1982.

[10]Jeremy Harmer. How to Teach English. Pearson Longman,2007.

[11] Kris Van den Branden. Task-based Language Education: From Theory to Practice. Cambridge: Cambridge University Press,2006.

[12] B.L. Leaver \& J. Willis. Task-based Instruction in Foreign Language Education: Practices and Programmes. Washington, DC: Georgetown University Press,2005.

[13] Marie-Noelle Lamy. Online Communication in Language Learning and Teaching. Paigrave Macmillan, 2007.

[14] T. Pica. Questions from the Language classroom: Research Perspectives. TESOL Quarterly, 28 (1994) 49-79.

[15] D. Willis. Rules, Patterns and Words: Grammar and Lexis in English Language Teaching. Cambridge University Press, 2003.

[16] P. Skehan. Task-based Instruction. Annual Review of Applied Linguistics, 18 (1998), 268-286.

[17] R. Ellis. Understanding Second Language Acquisition. Oxford: Oxford University Press, 1985.

[18] Michael Long. The Handbook of Second Language Acquisition. San Diego, CA: Academic Press, 1996.

[19] Z. Dörnyei and R. Schmidt. Motivation and Second Language Acquisition. Honolulu: University of Hawai’i, National Foreign Language Resource Center, 2001.

[20] V. Samuda and M. Bygate. Tasks in Second Language Learning. Basingstoke: Palgrave Macmillan, 2008.

[21] P. Coughlan and P. Duff. Vygotskian Approaches to Second Language Research. Norwood, NJ: Ablex Publishing Corporation, 1994. 
[22] S.P. Dundis and S.G. Benson. Understanding and Motivating Health Care Employees: Integrating Malsow's Hierarchy of Needs, Training and Technology. Journal of Nursing Management, September, Vol.11m no.5 (2003),315-20

[23] M. Sawin. Communication Competence: Some roles of comprehensible input and comprehensible output in its development. in S. Gass, S \& Madden, C. (eds.). Input in Second Language Acquisition. Rowley, MA: Newbury House, 1985, pp.248-249

[24] Dave Willis and Jane Willis. Doing Task-based Teaching. Oxford University Press, 2007, pp. $25-42$

[25] L.F. Bachman and A.S. Palmer. Language Testing in Practice: Designing and Developing Useful Language Test. Oxford: Oxford University Press, 1996.

[26] Z. Dornyei, Z. Teaching and Researching Motivation. Longman Pearson,2001.

[27] D.A. Wilkins, D.A. Linguistics in Language Teaching. London: Edward Arnold, 1972.

[28] B. Spolsky. Conditions for Second Language Learning. Shanghai: Shanghai Foreign Language Education Press, 2000. 